Ks. Leszek Misiarczyk ${ }^{1}$

\title{
Gdzie leżał starożytny Strydon? Przegląd najważniejszych hipotez jego lokalizacji
}

\section{Wstęp}

Jak wiemy, Hieronim (347-419) to doskonały znawca literatury i kultury łacińskiej, zwłaszcza pism Cycerona, i jedna z ważniejszych postaci Kościoła łacińskiego na przełomie IV i V wieku². W starożytności chrześcijańskiej i średniowieczu tematyka lokalizacji miejsca pochodzenia Hieronima nie budziła większego zainteresowania. Przez całe wieki bazowano na informacji przekazanej przez niego samego w De viris illustribus 135, że pochodził z oppido Stridonis, który leżał na dawnej granicy pomiędzy Panonią i Dalmacją (Dalmatiae quondam Pannoniaeque confinium) ${ }^{3}$. Choć bardzo trudno było ustalić, jaki okres czasu miał na myśli autor, używając owego quondam, jak też określić dokładny przebieg granicy pomiędzy Panonią i Dalmacją na przestrzeni dziejów, to jednak przypuszczano, że Strydon leżał gdzieś na terenie dzisiejszej północnej Chorwacji. Ponieważ z różnych pism Hieronima wynika wyraźnie, iż miał on przyjaciół w starożytnych miastach, takich jak Altinum (Akwileia), Concordia i Haemona (dzisiejsza Ljubljana), słusznie zakładano, że an-

1 Ks. prof. dr hab. Leszek Misiarczyk, kierownik Zakładu Badań nad Historią Kościoła w Starożytności w Instytucie Historii na Wydziale Nauk Historycznych Uniwersytetu Kardynała Stefana Wyszyńskiego w Warszawie; email: 1.misiarczyk@uksw.edu.pl; ORCID: 0000-0002-9511-6174.

2 Szerzej zob. J. Czuj, Św. Hieronim. Żywot, dzieła charakterystyka, Warszawa 1954; J. Quasten, Patrologia, t. 3, Casale Monferrato 1983, s. 203-240.

3 Hieronymus Stridonesis, De viris illustribus 135, PL 23, 756. 
tyczny Strydon musiał leżeć gdzieś w pobliżu nich. Trudno bowiem sobie wyobrazić, aby jako młody człowiek szukał on sobie przyjaciół w miastach bardzo odległych od miejsca swego zamieszkania. Do dzisiaj wielu badaczy życia i pism Hieronima poprzestaje na ogólnym stwierdzeniu, które zyskało konsensus większości uczonych, że Strydon leżał gdzieś w pobliżu dawnej granicy Dalmacji i Panonii, niezbyt daleko o dzisiejszej Ljubljany i Akwilei ${ }^{4}$. Inni starali się i nadal próbują identyfikować go z różnymi konkretnymi miejscowościami, co prowadzi oczywiście do wielu wzajemnie wykluczających się hipotez. W efekcie tych badań historycy i archeologowie zaproponowali cztery różne miejsca lokalizacji antycznego Strydonu ${ }^{5}$. Zobaczmy je teraz szczegółowo.

\section{Cztery hipotezy}

Najbardziej zacięte dyskusje na temat identyfikacji starożytnego Strydonu miały miejsce w XVI wieku pomiędzy włoskimi i dalmackimi humanistami, z których pierwsi opowiadali się zdecydowanie za Istrią, drudzy natomiast oczywiście za Dalmacją ${ }^{6}$. Druga fala zaciekłych dysput naukowych na ten temat pojawia się w drugiej połowie XIX i na początku XX wieku. Większość jednak opracowań powstałych pomiędzy XVI a początkiem XX wieku inspirowała się bardziej lokalnym patriotyzmem niż opierała na solidnej analizie naukowej. W ten sposób zaproponowano cztery hipotezy na temat miejsca pochodzenia Hieronima: Istria/Italia, Panonia, Dalmacja i Bośnia. Wszystkie były oparte na tzw. homofoniach, czyli podobieństwach w brzmieniu nazw niektórych dzisiejszych miejscowości z antycznym Strydonem. W zaproponowanych regionach zwolennicy każdej z hipotez starali się doszukać takiej miejscowości, której nazwa

4 Por. Quasten, Patrologia, t. 3, s. 203. J. N. D. Kelly (Jerome: His Life, Writings and Controversies, London 1975, s. 15) jest zdania, że Strydon leżał na terenie Italii, na południe od Akwilei. Zob. S. Rebenich, Jerome: The Early Church Fathers, New York 2002; J. Samur, St. Jerome of Stridon: His Influence on the Church, and His Translation of the Hebrew and Greek Scripture into the Latin Language (nieopublikowana drukiem praca doktorska).

5 Omawia je m.in. F. Sanjek, A la recherche de Stridon, lieu de naissance de saint Jérome, „Revue d'Histoire Ecclésiastique” 100/1 (2005) s. 146-151.

${ }^{6}$ Por. I. Ivič, The Cult of Saint Jerome in Dalmaia in the Fifteenth and the Sixteenth Centuries, Budapest 2016, s. 26-30; I. Ivič, Jerome Comes Home: The Cult of Saint Jerome in Late Medieval Dalmatia, „Hungarian Historical Review” 5/3 (2016) s. 618-644 (zw1. s. 621-622). 
byłaby najbardziej zbliżona do Strydonu. I tak starożytny Strydon utożsamiano ze Zdrinja/Sdringa w Istrii, ze Zrin/Strigovo niedaleko Medumurje na Węgrzech (dawna Panonia) albo z Grahovo (dzisiaj Bośnia) lub Skradin w Dalmacji ${ }^{7}$. Choć taka metoda identyfikacji starożytnego Strydonu Hieronima miała jednak niewiele wspólnego z rygorem badań naukowych i dzisiaj budzi poważne zastrzeżenia uczonych, to warto przyjrzeć się krótko każdej z hipotez i argumentom ich zwolenników.

\subsection{Istria}

W średniowieczu mieszkańcy Istrii wierzyli, że Hieronim urodził się gdzieś na ich terenie, na co wskazuje kult jego osoby potwierdzony przez księgi liturgiczne i kościoły jemu poświęcone ${ }^{8}$. To przekonanie spopularyzował w XVI wieku Flavius Blondus, który pisał ,[...] oppidulum, nunc nomine Sdrigna, quod fuisse constat olim Stridonis oppidum: Unde [...] Hieronymus originem duxit" . Autor nie przedstawił jednak żadnych konkretnych argumentów za swoją hipotezą, a jedynie stwierdził, że dzisiejsze miasteczko Sdrigna to dawny Strydon, z którego pochodził Hieronim. Do hipotezy Blondusa powrócił w następnym stuleciu Ireneo della Croce ${ }^{10}$ i kilka wieków później Petar Stancovich, który w swoim tekście opublikowanym w języku włoskim w 1824 roku konkludował: ,Stridone, già piccola città, come alcuni vogliono dell'Italia, negli antichi confini della Dalmazia e della Pannonia, situata cioè nell'Istria settentrionale"11. Podobnie jak poprzednicy również i on nie przedstawił jednak żadnych konkretnych argumentów za swoją hipotezą, jedynie stwierdzając, że Strydon leżał na obszarze antycznej Istrii. Warto zauważyć, że sam Hieronim nigdy nie wspomina

7 Por. M Suić, Hieronim Stridonjanin - gradanin tarsatike, „Rad JAZU” 426 (1986) s. 213-278.

8 Por. Ivič, The Cult of Saint Jerome in Dalmaia in the Fifteenth and the Sixteenth Centuries, s. 27. W Istrii średniowieczny kult Hieronima potwierdzony jest przez następujące rękopisy: Pierwszy Beramski Brewiarz (National Library in Ljubljana, Ms 161), który zawiera officium o św. Hieronimie, oraz Pierwszy Beramski Mszat (National Library in Ljubljana, Ms 162), który zawiera formularz specjalnej Mszy św. ku czci Hieronima. Z kolei w Sdrigna i Buzet (Istria) znajdują się kościoły poświęcone Hieronimowi.

9 Por. F. Blondus, Italia illustrata sive descriptio XIV regionum Italiae, Bazel 1539, s. 387.

10 Por. Ireneo della Croce, Historia di Trieste, Venetiae 1698.

11 Por. P. Stancovich, Della patria di S. Girolamo, dottore di s. Chiesa, e della lingua slava relativa alio stesso, Venezia 1824, s. 8. 
Istrii w swoich pismach, więc wygląda na to, że hipoteza ta nie jest oparta na żadnych historycznych przesłankach, ale jest raczej przejawem myślenia życzeniowego jej zwolenników. W późniejszych badaniach zarzucono hipotezę istryjską, gdyż nie przemawiał za nią żaden poważny argument historyczny i literacki. Kult Hieronima zaś na terenie Istrii sam z siebie nie wystarczy do udowodnienia jego pochodzenia stamtąd, gdyż kult ten mógł równie dobrze rozprzestrzeniać się z sąsiednich terenów.

\subsection{Panonia}

Stjepan Brodarić jako pierwszy wyraża przekonanie, że ziemia słowiańska była ojczyzną Marcina z Tours i Hieronima: „Sabaria divi Martini et Stridon divi Hieronymi patria"12. Autor identyfikował Strydon z mała miejscowością zwaną Strigova na granicy pomiędzy północną Chorwacją, Słowenią i Węgrami. Za taką samą lokalizacją Strydonu opowiedzieli się kolejno Antun Vramec ${ }^{13}$, Nicolas Olah ${ }^{14}$, Melchior Inhoffer ${ }^{15}$ i Josip Bedekovič, który doprecyzował, że chodzi o wieś niedaleko Medimurje, w dzisiejszej północnej Chorwacji ${ }^{16}$. Do hipotezy lokalizacji Strydonu w Panonii powrócił w XIX wieku Josephus Danko ${ }^{17}$ i na początku XX wieku Ferdo Šišić ${ }^{18}$. Zwolennicy panońskiego pochodzenia Hieronima opierają swoje wnioski głównie na informacji zachowanej w aktach Soboru Nicejskiego z 325 roku. Otóż w tych dokumentach, pod tekstem końcowym Soboru, znajdują się podpisy wszystkich jego uczestników podzielone według ówczesnych prowincji kościelnych. Znajdujemy w nich dwie informacje bardzo ważne dla niniejszych analiz. Po pierwsze, bardzo wyraźnie są

12 Zob. S. Brodarić, De conflictu Hungarorum cum Solymano Turcarum imperatore ad Mohach historia verissima, Cracovia 1527, s. 29.

13 A. Vramec, Kronika, Ljubljana 1578, f. 24v.

14 N. Olahus, Hungaria, Budapest 1536, r. VIII: „Hinc intra Muravum et Dravum fluvios est Strido, divi Hieronymi patria".

15 Por. M. Inhoffer, Annales ecclesiastici regni Hungariae, Romae 1644, Požun 1795, s. 156.

16 Por. J. Bedekovič, Natale solum magni ecclesiae doctoris Hieronymi in ruderibus Stridonis occultatum, Neostadii Austriae 1752, s. 173-176. Zob. także: Ivič, The Cult of Saint Jerome in Dalmaia in the Fifteenth and the Sixteenth Centuries, s. 28-29.

17 Por. J. Danko, Divum Hieronymum oppido Stridonis in regione interamna (Murakoz) Hungariae, Mainz 1874, s. 123.

18 Por. F. Šišić, Hrvatska povijest od najstarijih dana do potkraj 1918. sv. 1, Zagreb 1925, s. 109. 
od siebie odróżnione Provincia Dalamatiae i Provincia Panonie, co oznacza, że w pierwszej połowie IV wieku stanowiły one już odrębne prowincje kościelne. Wygląda więc na to, że ówczesne prowincje kościelne nie pokrywały się z podziałem administracyjnym na prowincje w cesarstwie, gdyż, jak wynika z informacji samego Hieronima, w jego czasach najprawdopodobniej już nie było granicy pomiędzy Dalmacją a Panonią. Po drugie, z Provinciae Dalamatiae wzięło udział w Soborze Nicejskim dwóch biskupów, Bonius Stoborum i Bodius Stobiorum, z Provinciae Panoniae natomiast tylko jeden, Domnus Stridonesis ${ }^{19}$. Informacja o biskupie z Panonii, który brał udział w Soborze w Nicei, mogłaby wskazywać, że ok. 325 roku, czyli ok. 20 lat przed narodzinami Hieronima, Strydon należał do prowincji kościelnej Panonii i byłby na tyle dużym ośrodkiem miejskim, że posiadałby własnego biskupa ${ }^{20}$. Dokładniejsze badania pokazały jednak, że w aktach Soboru Nicejskiego jest błąd i zamiast Stridonensis należy czytać Sirmiensis. Chodziłoby więc o starożytne Sirmium, czyli Sremską Mitrovicę, która była ważnym centrum i miała swojego biskupa Domnusa. Strydon zaś był zapewne niewielką osadą i nigdy nie posiadał własnego biskupa $^{21}$. Na początku XX wieku pojawiła się kolejna próba identyfikacji Strydonu ze Zrinem na terenie dzisiejszych Węgrzech ${ }^{22}$, ale hipoteza znowu nie przekonała badaczy. W latach osiemdziesiątych XX wieku powrócił do hipotezy panońskiej Istvan Fodor, który powołując się na dokumenty z 1271 roku (castrum Strido) i z 1333 (Strido), doszedł do wniosku, iż tradycja potwierdza ciągłość pomiędzy antycznym Strydonem i średniowiecznym Strido (Strigo). Stąd jego zdaniem Strido (Strigovo) najlepiej odpowiada opisowi Hieronima i powinno być utożsamione z jego miastem rodzinnym ${ }^{23}$. Hipoteza nie została jednak powszechnie zaakceptowana przez badaczy, którzy podkreślali, iż wydaje się mało prawdopodobne, aby antyczna Panonia mogła być prowincją, w której leżał Strydon Hieronima.

19 J. D. Mansi, Sacroroum Conciliorum Nova et Amplissima Collectio, t. 2, Florentiae 1759, k. 696.

20 Taką hipotezę zaproponował: A. Mayer, Die Sprache der alten Illyrien, Beč 1957 , s. 323: „Nach den nicäischen Konzilakten gehörte es (Stridon) im J. 325 zu Panonien”.

${ }_{21}$ Por. R. Bratož, Crkvenopolitični in kulturnozgodovinski odnosi med Sirmijem in Akvilejo, „Zgodovinski časopis” 37 (1983) s. 259-272 (tutaj s. 268).

22 Por. J. Florschütz, Stridon i Zrin, ,Vjesnik Arheoloskog Muzeja u Zagrebu” 6/1 (1902) s. 87-98.

23 Por. I. Fodor, Le lieu d'origine de S. Jerome. Reconsidération d'une vieille controversie, „Revue d'Historie Ecclésiastique” 81/3-4 (1986) s. 498-500. 


\subsection{Dalmacja}

Kult św. Hieronima w północnej Dalmacji znany był już w średniowieczu, co potwierdza wyraźnie wprowadzenie święta ku jego czci np. w Trogirze w 1454 roku, gdzie przekonywano, że powinien on być czczony ze względu na swojej dalmackie pochodzenie ${ }^{24}$. Marco Marulić, odrzucając zdecydowanie hipotezę istryjską/italską Blondusa i opierając się na geografiach antycznych, starał się wykazać, że Hieronim nie urodził się w Sdrigna, ale w pobliżu Skradin, które leżało na ziemi słowiańskiejes. W okresie odrodzenia popularność Hieronima znacząco wzrasta do tego stopnia, że zajmuje się nim nawet słynny Erazm z Rotterdamu ${ }^{26}$. W swoim dziele Eximii doctoris Hieronymi Stridonensis vita ex litteris eius potissimum conscripta ${ }^{27}$ odrzuca zdecydowanie wszelkie wydarzenia legendarne z życia Hieronima oparte na rzekomych listach Cyryla Jerozolimskiego, Euzebiusza z Cremony i Augustyna, a także identyfikację Strydonu ze Sdrigna przez Blondusa oraz uznawanie Hieronima za mieszkańca Italii i przypisywany mu tytuł kardynała ${ }^{28}$. Dla niniejszych analiz najważniejszy jest fakt, że Erazm przeciwstawia się hipotezie Blondusa i uznawaniu Hieronima za mieszkańca starożytnej Italli oraz opowiada się za hipotezą Marulića identyfikacji Strydonu ze Skradin (Scardona) w Dalmacji. Można jednak mieć poważne wątpliwości co do lokalizacji Strydonu przez Marulića i Erazma na ziemiach słowiańskich. Hipoteza o słowiańskich korzeniach Hieronima znana była już w XVI wieku. Za Merulićem i Erazmem powtórzył ją mnich hiszpański José de Espinoza de Sigüenza, twierdząc wręcz,

24 Por. Ivič, The Cult of Saint Jerome in Dalmaia in the Fifteenth and the Sixteenth Centuries, s. 28. Potwierdzają to statuty miasta Trogir: Statut i reformacja grada Trogira, Monumenta historico-juridica Slavorum meridionalium, 10, ed. I. Storhal, Zagreb 1915, ch. 64.

25 Por. Marci Maruli, In eos qui beatum Hieronymum Italum esse contendunt, w: J. Lucius, De regno Dalmatiae et Croatiae, Amsterdam 1666, s. 457. Zob. także Marci Maruli, Vita divi Hieronymi, ed. D. Novaković, „Colloqua Maruliana” 3 (1994) s. 25-53.

26 F. Cavallera, Saint Jerôme, sa vie, son ouvre, t. 1-2, Louvain - Paris 1922; E.F. Rice, Saint Jerome in the Renaissance, Baltimore - London 1985.

27 Erazm z Rotterdamu, Eximii doctoris Hieronymi Stridonensis vita ex litteris eius potissimum conscripta, ed. W.K. Ferguson, Erasmi Opuscula, Hague 1933, s. 134-190.

28 Por. Ch. Béné, Marulić et Erasme, Lecturs de Saint Jérôme, „Colloquia Maruliana" 10 (2001) s. 29-45; V. Grubišć, Trojica Humanista o Rodnome Mjestu Svetog Jeronima: Flavio Biondo, Marko Marulić i José de Espinoza de Sigüenza (The Humanists on the Birthplace of Saint Jerome: Flavius Blondus, Marko Marulić and José de Espinoza de Sigüenza), „Colloquia Maruliana” 17 (2008) s. 287-297. 
że Hieronim wynalazł alfabet słowiański i przetłumaczył Pismo Święte na język słowiański ${ }^{29}$. Nigdy jednak ta hipoteza nie była traktowana poważnie przez uczonych. Wiemy, że ludy słowiańskie docierają na teren dzisiejszej Słowenii i Chorwacji kilka wieków później, więc zwyczajnie niemożliwe jest ze względów chronologicznych, aby Hieronim był Słowianinem, który miał stworzyć alfabet słowiański i przetłumaczyć Pismo Święte na język słowiański, a jego Strydon leżał na ziemiach Słowian ${ }^{30}$. Hipoteza Marulića częściowo została zaakceptowana w późniejszych wiekach i wielu badaczy zgadzało się, że Strydon Hieronima leżał gdzieś w Dalmacji, ale nie było zgody co do jego konkretnej lokalizacji oraz przyjęcia założenia, że Dalmacja była już wtedy słowiańska. W XIX wieku do badań powrócił Joahnnes Capor, który odrzucił zdecydowanie hipotezę istryjską Stancovicha, opowiadając się ponownie za Dalmacją jako regionem, w którym miał znajdować się antyczny Strydon ${ }^{31}$, ale nie przedstawił znowu żadnych nowych argumentów za swoją hipotezą.

Zwolennicy lokalizacji Strydonu w Dalmacji powołują się na słowa Palladiusza, biskupa z Heliopolis w Bitynii, który początkowo był przyjacielem Hieronima i nawet odwiedził go w Betlejem, ale później pokłócił się z nim i zerwał z nim wszelkie kontakty. Informacja pochodzi z okresu już po ich rozstaniu się, więc nie dziwi nas fakt, iż zawiera odrobinę złośliwości i pogardy wobec Hieronima oraz miejsca jego pochodzenia. Palladiusz, przedstawiając w Historia Lausiaca życiorys Pauli rzymianki, podkreśla złośliwie, że przeszkodą jej wzrastania w świętości „był pewien

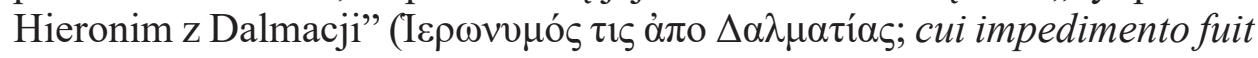
Hieronymus quidam Dalmata ${ }^{32}$. Nawet jeśli użył on tutaj zwrotu ogólnego „pewien” ( $\tau \iota \varsigma$, quidam), to jednak nie ma wątpliwości, że chodzi o naszego Hieronima. Ciekawe, że Rufin, początkowo przyjaciel Hieronima, później zaś jego zaciekły przeciwnik, który choć pochodził z Konkordii a potem osiadł w Akwilei, wiedział zapewne dokładnie, gdzie leżał Strydon, to jednak nic o tym nie wspomina. Rufin, choć w polemikach używał przeciw

29 Zob. José de Espinoza de Sigüenza, Vida de San Gerónimo Doctor de la Santa Iglesia, Madrid 1595; J.V.A. Fine, The Slavic Saint Jerome: An Entertainment, „Harvard Ukrainian Studies" 22 (1998) s. 101-112.

30 J. Verholantsev przekonująco rozprawiła się z tymi legendami w swoim dziele. Zob. J. Verholantsev, The History of the Legend and Its Legacy or How the Translator of the Vulgate became an Apostle of the Slaves, DeKalb 2014.

31 Por. I. Capor, Della patria di san Girolamo, risposta di Giovanni Capor dalmatino, all'opuscolo del can. D. Pietro Stancovich istriano, Roma 1828.

32 Palladius, Historia Lausiaca 125, PG 32, 1233. 
Hieronimowi argumentów ad personam, to jednak nigdy nie posunął się od ośmieszania miejsca jego pochodzenia. Wiemy, że Rufin i Palladiusz byli zwolennikami nauk Orygenesa, które Hieronim, po początkowym zachwycie, potem krytykował, więc pewnie dlatego z pogardą pisali też o nim samym i o jego Dalmacji. Nie wiemy jednak, jak do końca traktować to przypisywanie Hieronimowi pochodzenia dalmackiego: on sam tak się przedstawiał czy raczej Palladiusz po prostu określił go pogardliwie Dalmatą bez dociekania, gdzie dokładnie się urodził i wychował. Zwolennicy hipotezy dalmackiej szukali Strydonu gdzieś w centrum starożytnej Dalmacji, ale należy tutaj chyba bardziej wierzyć samemu Hieronimowi, który umieszczał Strydon na dawnym pograniczu Dalmacji i Panonii. Podstawą do wszelkich badań na ten temat pozostaje nadal autoprezentacja Hieronima w De viris illustribus 135.

Od dawna uwagę badaczy przykuło owo słynne quondam (niegdyś) oraz que z Pannoniaeque w zwrocie Dalmatiae quondam Pannoniaeque confinium fuit. Jak rozumieć to określenie? Jako Dalmatiae et quondam Pannoniae confinium fuit i wtedy oznaczałoby to, że tylko granice Panonii zostały zmienione, czy też jako Dalmatiae quondam et Pannoniae confinium fuit, co trzeba by rozumieć, że zarówno granice Dalmacji, jak też Panonii uległy zmianie. Bardzo trudno jest udzielić tutaj ostatecznej odpowiedzi, gdyż rejon ten doświadczał ciągłych zmian granic w starożytności. Co zatem miał na myśli Hieronim, używając określenia „niegdyś” (quondam)? Najprawdopodobniej owo quondam odnosi się do czasów sprzed reorganizacji prowincji przez cesarza Augusta i zniesieniem granic pomiędzy Dalmacją i Panonią, czyli pod koniec czasów republiki i na początku cesarstwa. Hieronim pisał więc w czasie, kiedy granicy pomiędzy Dalmacją a Panonią już nie było i dlatego użył terminu quondam ${ }^{33}$.

Ostatnio Rafko Valenčič, polemizując ze starym tekstem Miroslava Premrou (Della patria di s. Girolamo, Milano 1920), twierdził, że nie można przypisać owemu quondam znaczenia sprzed panowania Augusta, gdyż jest ono typowo Hieronimowe i opisuje sytuację z IV wieku ${ }^{34}$. Próżno jednak szukać argumentów, na podstawie których autor uważa, że quondam, które było dosyć powszechnie używane w IV i V wieku, nosi rysy typowo Hieronimowe i opisuje stan z IV wieku. Hieronim użył quondam, gdyż wiedział, że w jego czasach granicy pomiędzy Panonią i Dalmacją w ogóle nie

33 Bulić, Dove era Stridone, la casa di San Girolamo, s. 139; Suić, Hieronim Stridonjanin - gradanin tarsatike, s. 223-225.

34 Por. R. Valencić, Miroslav Premrou, Della patria di s. Girolami, „Arhivi” 37/1 (2014) s. 11-29 (tutaj s. 19). 
było albo przebiegała ona w zupełnie innym miejscu. Valenčič opowiada się również za szerokim rozumieniem terminu confinium w tym sensie, że Strydon niekoniecznie musiał leżeć dokładnie na samej granicy pomiędzy Panonią a Dalmacją, ale gdzieś w pobliżu. Ten sam autor, powołując się na pismo Hieronima przeciw Rufinowi, który żali się, iż jego były przyjaciel rozpowszechnił na jego temat oszczerstwa w Rzymie, Itali i na wyspach Dalmacji (Dalmatiae insulas), dochodzi do wniosku, że Hieronim znał tak naprawdę tylko wyspy Dalmacji. Ponieważ nigdy nie wspomina Dalmacji jako stałego lądu, stąd jego zdaniem nie mógł być Dalmatą. Valenčič, powołując się na wyżej przytoczone argumenty oraz fakt, iż Hieronim nazywa swojego przyjaciela Castrucjusza homo Pannonicus, konkluduje, że Strydon nie leżał w Dalmacji, ale w Panonii ${ }^{35}$. Jak widać, stare hipotezy lokalizacji Strydonu wciąż pojawiają się w nowszych opracowaniach.

\subsection{Grahovo w Bośni}

Pierwszym uczonym, który podjął się szczegółowego przebadania problemu lokalizacji dawnego Strydonu, stosując nowoczesne, jak na tamte czasy, metody analizy źródłowej, był Frane Bulić ${ }^{36}$. W oparciu o informacje samego Hieronima przekazane w trzeciej osobie w De viris illustribus z 392 roku doszedł do wniosku, że miejscem urodzin i życia Hieronima było Grahovo (dzisiaj w Bośni i Heregowinie) ${ }^{37}$. Oto tekst z De viris: „Hieronymus natus patre Eusebio, oppido Stridonis, quod a Gothis eversum Dalmatiae quondam Pannoniaeque confinium fuit" ${ }^{38}$. Bulić w swoich

35 Valencić, Miroslav Premrou, Della patria di s. Girolami, s. 20-22.

36 Artykuł ukazał $w$ różnych latach w językach niemieckim, włoskim i chorwackim. Por. F. Bulić, Wo lag Stridon, die Heimat des hl. Hieronymus, w: Festschrift für Otto Bendorf zu seinen 60, Geburtstag, Beč 1898, s. 276-280; F. Bulić, Dove era Stridone, la casa di San Girolamo, „Bullettino di archeologia e storia dalmata” 22 (1899) s. 137-142; F. Bulić, Stridon, Grahovo polje u Bosni, rodno mjesto sv. Jeronima, ,Vjesnik za arheologiju i historiju dalmatinsku" 43 (1920) s. 60-110. Zob. także późniejsze jego publikacje: F. Bulić, Stridone luogo natale di S. Girolamo, w: Miscelanea Geronimiana Scritti varii publicati nel XV centenario, red. V. Vannutelli, Roma 1920, s. 253-330; F. Bulić, Izbrani radowi, Split 1984, s. 87-198.

37 Za jego hipotezą idzie: Czuj, Św. Hieronim. Żywot, dzieła charakterystyka, s. 5: „Euzebiusz Hieronim, syn Euzebiusza, urodził się w Strydonie w Dalmacji (dzisiejsze Grahovo Polje, niedaleko Lublany)". Warto podkreślić, że Grahovo Polje nie leży koło Ljubljany, ale w dzisiejszej Bośni i Hercegowinie.

38 Hieronymus Stridonesis, De viris illustribus 135, PL 23, 756. 
poszukiwaniach topograficznych skoncentrował się na zwrocie Dalmatiae quondam Pannoniaeque confinium fuit i szukał owej dawnej granicy pomiędzy Dalmacją i Panonią w dzisiejszych górach Dinar. Dowodem na to jego zdaniem miała być inskrypcja odkryta w XIX wieku:

\section{IVO EX//////AIVSAILA \\ VIOVAIFPIO CONS \\ IAVIIO/////P POELM \\ FIVS / VIEP SALV \\ I A I A S E I S I P IODO \\ VEV SES O EIEPM \\ I V A V I I}

Rekonstrukcji inskrypcji dokonał Alacevich, który, publikując ją, zaproponował takie jej brzmienie: ,[...] iu[d]ex [d]a[t]us a [F]la/vio Va[ler] io Cons/[t]a[nt]io v[iro] c[larissimo] p[raeside] p[rovinciae] [D]elm[atiae]/ [f]i[ne]s i[nt]e[r] Salv/ia[t]as et S[tr]ido/[n]e[n]ses [d]e[t]e[r] $m / i[n]$ avi $[t] " 39$. Tekst wspomina o Flawiuszu Waleriuszu Konstantynie, późniejszym cesarzu Konstantynie Chlorusie, ojcu cesarza Konstantyna Wielkiego. Za panowania cesarza Marka Aureliusza Numeriana (282/3283/4) został on podniesiony do rangi Praeses, czyli zarządcy prowincji Dalmacji, którą zarządzał w latach 282-288. W 288 roku przestał pełnić tę funkcję i przez cesarza Maksymina (285-305) został ustanowiony Prefectus Pretorium na zachodzie cesarstwa, w latach 287-288 zaś pod wodzą Maksymiana prowadził walki z plemieniem Allemanów, docierając aż do Renu i Dunaju. Inskrypcja wzbudziła jednak poważne wątpliwości badaczy, gdyż zawiera pewne anachronizmy i niedokładności ${ }^{40}$. Po pierwsze, nomen gentile Valerius został dodany Flawiuszowi Konstantynowi później, więc wygląda na to, że inskrypcja powstała również później, nawet jeśli dotyczy realiów drugiej połowy III wieku. Po drugie, użyte na początku terminy iudex datus wskazuje na trwający nadal konflikty między społecznościami lokalnymi a administracją cesarstwa rzymskiego. Odzwierciedla on jednak bardziej sytuację z czasów Trajana (98-117) i z tego okresu

39 G. Alacevich, La via romana da Sirmio a Salona, „Bulletino di archeologia e storia dalmata" 8 (1881-1882) s. 45-52.

40 Por. G. Morin, A-t-on retrouvé Stridon, le lieu natal de Saint Jérome?, w: Strena Buliciana/Bulicév Zbornik, Zagrebiae 1924, s. 421-432; G. Morin, La patrie de Saint Jérome, le missorium d'Exsuperius: deux rétractations nécessaires, „Revue Bénédictine” 38 (1926) s. 217-220. 
pochodzi większość inskrypcji, która go zawiera. Pojawienie się zwrotu w inskrypcji z III wieku brzmi dosyć anachronicznie, kiedy to już od czasów edyktu Karakalii z 212 roku, który przyznawał obywatelstwo rzymskie wszystkim mieszkańcom cesarstwa, romanizacja Dalmacji postępowała bardzo intensywnie i włączano mniejsze wspólnoty do większych jednostek administracyjnych. Gdyby inskrypcja była autentyczna, wtedy trzeba by przyjąć, że Strydon był centrum większej społeczności i wytyczano nowe granice między nim a Salvium, Flawiusz Konstantyn zaś fines inter Salviatas et Stridonenses determinavit. Kolejnym anachronizmem, którego nie zauważył autor inskrypcji, jest określenie całej prowincji jako Delmacja, a nie Dalmacja, jak zawsze była nazywana ${ }^{41}$. Bulić początkowo pozostawał niewzruszenie przy swoim przekonaniu, że inskrypcja jest autentyczna, gdyż pasowało mu to dobrze do przyjętego wcześniej założenia. Ostatecznie jednak dał się przekonać, że jest ona późniejsza i nie odzwierciedla sytuacji historycznej z drugiej połowy III wieku. Niewykluczone, że zaproponowane przez Bulića Grahovo jest pozostałością jakiejś starożytnej osady, ale to nie był Strydon Hieronima. Granica pomiędzy Panonią i Dalmacją mogła przebiegać mniej więcej w tym miejscu w okresie przed panowaniem cesarza Oktawiana Augusta, który dokonał reorganizacji prowincji ${ }^{42}$, w III wieku natomiast raczej nie przebiegała w górach Dinara ${ }^{43}$. Dzisiaj większość badaczy przyjmuje, że inskrypcja jest falsyfikatem. Salvium rzeczywiście istniało w tym rejonie i było municipium, podczas gdy Strydon, według opinii samego Hieronima, był osadą rolniczą. Choć w De viris on sam używa określenia oppidum, to Stridon był raczej małym ośrodkiem społeczności wiejskiej, który pozostawał włączony w większą społeczność terytorialną, municipium lub civitas. Używając określenia oppidum, Hieronim chciał zapewne trochę na wyrost przedstawić miejsce swego pochodzenia jako miasteczko. Jeśli inskrypcja jest fałszywa, z oczywistych względów nie można na niej opierać poszukiwań Hieronimowego Strydonu i trzeba szukać innych źródeł.

41 Por. M. Suić, Hieronim Stridonjanin-gradanin tarsatike, s. 21.

42 Na temat reform administracyjnych Oktawiana, por. A. Ziółkowski, Historia starożytna, Warszawa 2009, s. 822-844; K. Christ, Historia cesarstwa rzymskiego od Augusta do Konstantyna, Poznań - Gniezno 2016, s. 155-167.

43 Zob. Christ, Historia cesarstwa rzymskiego od Augusta do Konstantyna, s. 155167; A. Mayer, Stridon, „Vjesnik Arheoloskog Muzeja u Zagrebu” 22-23/1 (1942) s. 175185; I. Fodor, Le lieu d'origine de S. Jérôme. Reconsidération d'une vielle controverse, „Revue d'Histoire Ecclésistique” 81 (1986) s. 498-500. 


\section{Hipoteza Mate Suića: Hieronymus, domo Stridonis, civis Tarsaticensis}

Mate Suić w swoim artykule z 1986 roku przedstawił krytyczną ocenę dotychczasowych propozycji i sam zaproponował nową lokalizację Strydonu ${ }^{44}$. Na początku podkreślił więc, że choć do dzisiaj nie udało się określić dokładnej lokalizacji Strydonu, to jednak wśród uczonych, głównie archeologów chorwackich i słoweńskich, przeważa opinia, że Strydon Hieronima (albo lepiej Stridonae, gdyż określenie to obejmowało szerszy obszar) powinien być poszukiwany gdzieś pomiędzy Akwileją, Konkordią i Ljubljaną. Odrzucił hipotezę Bulića, ponieważ opierała się ona błędnie na granicach średniowiecznej Dalmacji, a nie na czasach rzymskich. Suić wziął pod uwagę kilka elementów: wszystkie spisane źródła, a nie tylko De viris illustribus, wspomnienia samego Hieronima o swoim miejscu rodzinnym, zmianę granic rzymskich prowincji oraz porównał topografię dawnych łacińskich nazw ze współczesnymi chorwackimi nazwami miejscowości. Archeologowie odkryli, że pod koniec IV wieku zostały zbudowane mury obronne wzdłuż odgałęzienia Alp Julijskich znanych w źródłach jako Claustra Alpium Iuliarum. Jego zdaniem Hieronim pochodził z terenów peryferyjnych starożytnej Dalmacji, czyli Liburni. Suić jest zdania, że dawna granica pomiędzy Panonią a Dalmacją przebiegała właśnie w rejonie Liburni i biegła dalej w kierunku Alp Julijskich. Pewien diakon o imieniu Tomasz, kronikarz ze Splitu z XIII wieku, pisał, że Dalmacja rozpoczynała się w Epirusie, gdzie jest Durres, i rozciągała się aż do zatoki Kvarner (dzisiaj region zwany jest Opatia Kras), w głębi lądu zaś było miasto Strydon, na granicy pomiędzy Dalmacją i Panonią, miejsce narodzenia Hieronima. Choć hipoteza wydaje się prawdopodobna, to jednak dwa elementy pozostają nadal niejasne. Po pierwsze, nie przeprowadzono jeszcze dokładnych wykopalisk w rejonie, w którym Suić lokalizuje Strydon. Po drugie, jego założenie, że Tomasz, kronikarz ze Splitu z XIII wieku, miał dostęp do wcześniejszych źródeł, które zaginęły, domaga się weryfikacji ${ }^{45}$. Świadectwo jest co prawda bardzo późne, ale dobrze współbrzmi z aluzjami Hieronima o granicy Alp, którą nazywa kilka razy Alpes Iulias albo Alpium vallum ${ }^{46}$. Oznacza to, że Hieronim

44 Por. M. Suić, Hieronim Stridonjanin - gradanin tarsatike, „Rad JAZU” 426 (1986) s. 213-278.

45 Por. Ivič, The Cult of Saint Jerome in Dalmaia in the Fifteenth and the Sixteenth Centuries, s. 30.

46 Por. m.in. Hieronymus Stridonensis, Epistula ad Heliodorum (60) 16, CSEL 54, pars 1, s. 570; Hieronymus Stridonensis, Epistula ad Geruchiam (123) 16, CSEL 56, pars. 3, s. 93; Hieronymus Stridonensis, Commentariorum in Osee Prophetam I 4, 3, PL 25, 822. 
znał dokładnie i szczegółowo topografię tego rejonu, więc można przypuszczać, że właśnie tam znajdowały się jego posiadłości, które później zostały zniszczone przez Gotów. Nazywa on co prawda Strydon oppidum, ale w tym przypadku nie chodziłoby o municipium, ale raczej o castellum, gdyż właśnie w Kras odkryto ślady starożytnej fortecy. W tym rejonie zostały zbudowane miasta Šapjane, Pasjak i Starad wzdłuż drogi prowadzącej z Tarsatika (Rijeka) do Akwileii, która miała także swoje odgałęzienie do Tergeste (Triestu). Prawdopodobnie wszystkie te miasta były włączone do Claustrum.

Hieronim napisał swoje De viris illustribus w 392 roku, kiedy już sprzedał swoją własność. Goci zniszczyli jego oppidum i okoliczne wsie, bo gdy sprzedawał swoją posiadłość, była ona w połowie zrujnowana (semirutae). To oznacza, że inwazja Gotów na teren Claustrum miała miejsce krótko po zwycięstwie pod Hadrianopolem w 378 roku, która jest wspominana jako funus Illyrici. W Epistula ad Iulianum Hieronim wspomina o tym, że Goci splądrowali posiadłość jego sąsiada Juliana i zabrali mu stada zwierząt ${ }^{47}$. List pochodzi z 406 roku i prawdopodobnie odnosi się do sytuacji z 401 roku, kiedy to Goci ruszyli na Italię. Ucierpiał wtedy cały rejon Tarsatica, czyli dzisiejszej Rijeki, ale reszta Dalmacji pozostała raczej nietknięta. Tym razem Goci ruszyli w kierunku Dunaju, dwa razy przeszli rzekę i korytarzem przez Panonię dotarli do Savia, skąd rozprzestrzenili się na Claustrum (w tym czasie budowano masywne mury w Tarsatica). Nie ma żadnych tekstów literackich ani jakichkolwiek śladów archeologicznych, że Goci w 401 roku zmierzali do Italii przez Dalmację, choć taka teza jest lansowana przez zwolenników lokalizacji Strydonu na polu Grahovo. Hipoteza o zniszczeniu przez Gotów nadmorskich miast Dalmacji w 401 roku, w tym słynnej Salony, nie ma podstaw. Strydon leżał więc wzdłuż dawnej granicy pomiędzy Dalmacją i Panonią w kierunku granicy z Istrią. Suić odtwarza te granice z dosyć dużą dokładnością. Rozpoczyna od stwierdzenia, że granice Dalmacji w odróżnieniu od Panonii nigdy nie były zmieniane od czasów Augusta. Jego zdaniem nie ma więc podstaw dla hipotezy Degrassiego ${ }^{48}$, że już za czasów Augusta granica przebiegała przez dolny bieg rzeki Raša (Arsia) do Učka i dalej w kierunku Jelšani. Nieprzekonujące jest również twierdzenie oparte na Tabula Imperii Romani - Tergeste, według której granica biegła wzdłuż kanionu Rječina i dzieliła rejon Tarsatica na dwie części. Jeśli jednak cała okolica Strydonu należał do Dalmacji, a dokładniej Liburni, wtedy granicę między Liburnią a Istrią trzeba przesunąc bardziej na zachód, do miejsca

47 Hieronymus Stridonensis, Epistula ad Julianum (118) 2-3, CSEL 55, pars 2, s. 435-436.

48 Por. A. Degrassi, Il confine nord-orientale dell'Italia romana, Bern 1954. 
Starad, gdzie prawdopodobnie była stacja Ad titulos. A to oznaczałoby, że dawna granica rozpoczynała się w Raša, dalej przebiegała przez Ćićarija, kontunuując z Mune do Starady po dzisiejszej linii kolejowej.

Poniżej dołączam rekonstrukcję rejonu wykonaną przez Suića:

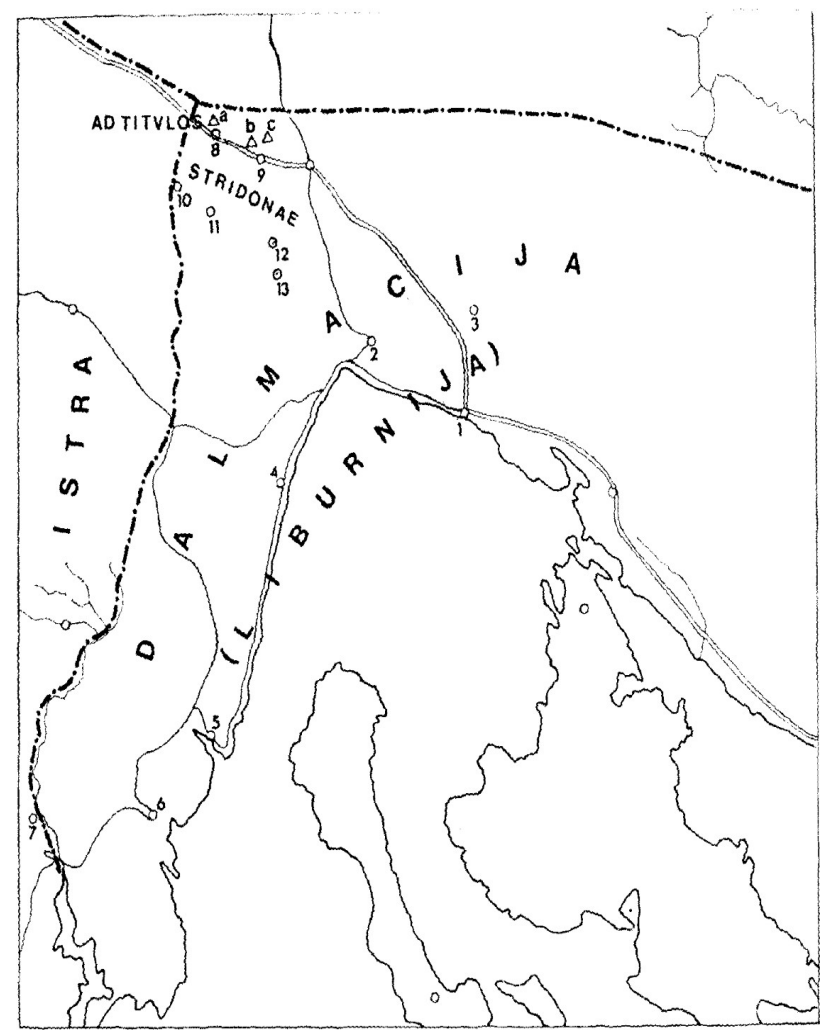

GRANICE DALMACJI I CHORWACJI

$\begin{array}{cc}\text { a }- \text { Starad } & 6 \text { Albona } \\ \text { b- Pasijak } & 7 \text { Alvun (?) } \\ \text { c u šapjanama } & 8-\text { Starad } \\ \text { 1- Tarsatika } & 9 \text { - šapjane } \\ 2 \text { - Kastav } & 10-\text { Mune } \\ 3 \text { - Prezid } & 11-\text { žejane } \\ 4 \text { - Lovran } & 12-\text { Brgud } \\ \text { 5- Flanona } & 13-\text { Zvoneće }\end{array}$


Hieronim, podkreśla dalej Suić, był właścicielem dużego majątku ziemskiego i miał mentalność wiejskiej arystokracji, co w jego dziełach potwierdza zwłaszcza postawa wobec niewolników, farmerów i klientów. Jego gospodarstwa musiały mieć jednak inny charakter niż pozostałe, gdyż, jak pamiętamy, on sam i jego brat byli przez długi czas nieobecni, więc musiał nimi kierować jakiś zarządca. Przed swoim wyjazdem z Rzymu do Betlejem Hieronim opisuje atmosferę miejsca swoich narodzin, wychwalając życie wiejskie i tak właśnie wyobraża sobie życie wieczne. W ekonomice synów Euzebiusza dominowała hodowla bydła, uprawa zboża i obróbka drewna, nie było zaś w Kras dobrych warunków dla upraw typowo śródziemnomorskich. Z tekstów Hieronima wynika również, że miał on dobre relacje z żołnierzami rozlokowanymi w Claustrum, co było charakterystyczne w tamtych czasach. Obrona Claustrum bowiem była słusznie postrzegana jako obrona również majątków ziemskich wzdłuż limes alpejskiego. W rejonie, gdzie mieszkał i dorastał Hieronim, ludność autochtoniczna mówiła zapewne mieszaniną dialektu weneckiego, istryjskiego i liburniańskiego z dodatkami celtyckiego i prostej łaciny, której używali żołnierze w Claustrum. Ponieważ pochodził on z zamożnej rodziny wielkich właścicieli ziemskich, żył w izolacji wobec okolicznej ludności a jego predylekcja od dzieciństwa do łaciny klasycznej sprawiła, że nie interesował go zbytnio język lokalnej ludności. Gdy pisał o swoim języku, używał zazwyczaj określenia „nostra lingua” albo „,sermo patrius”, mając na myśli oczywiście język łaciński, gdy natomiast miał na myśli lokalną mowę, nazywał ją „,sermo domesticus”, „sermo peregrinus”, ,sonus peregrinus” lub „sermo barbarus/gentilis”. Język łaciński (patrius, proper), i to w wersji jak najbliższej klasycznej, był jego językiem do wyrażania myśli i uczuć, inne języki lub dialekty nie były odpowiednie ku temu, nawet codzienna łacina, którą korygował, poprawiając tłumaczenie Wulgaty.

Strydon, konkluduje Suić, nie był więc ani municipium ani civitas i nie mógł mieć swego własnego biskupa, Hieronim zaś sam opisuje swój homeland jako teren wiejski. W administracji kościelnej Strydon przynależał do Tarsatica, która posiadała w IV wieku swojego własnego prezbitera. Hieronim w Epistula ad Julianum, diaconum Aquileiae z 374 roku dziękuje Julianowi za to, że otoczył duchową troską jego siostrę i pomógł jej w nawróceniu. Dodaje, iż nawet jeśli „Iberyjska żmija” rzuca na niego kalumnie, nie obawia się sądu ludzkiego, gdyż Bóg będzie go sądził. Ową „Iberyjską żmiją”, jak wyjaśnia sam Hieronim w następnym liście Ad Chromatium, Iovinum, Eusebium, jest prawdopodobnie kapłan Lupcinus, przyjaciel ich domu, który uwiódł jego siostrę, która wcze- 
śniej była prawdopodobnie mniszką. Hieronim podkreśla, że to dzięki świętemu Julianowi „odzyskał ją żywą” i prosi teraz tych trzech swoich przyjaciół, aby jego siostrze dobrze radzili i wspierali ją, gdy już wróciła na właściwą drogę. Nie określa Lupcinusa mianem ,prezbiter”, ale na wzór kapłanów pogańskich sacerdos, by jeszcze bardziej podkreślić jego niegodność bycia prezbiterem Kościoła katolickiego. Trudno sobie wyobrazić, że ów prezbiter Lupcinus z antycznej Tarsatica (dzisiejsza Rijeka) wędrował dziesiątki albo wręcz setki kilometrów, aby spotkać rodzinę Hieronima a potem uwieść jego siostrę. Musiał u nich przebywać dosyć często, a to oznacza, że odległość między Strydonem a Tarsatica nie mogła być duża. Dalej, List do diakona Juliana z Akwielei wskazuje również, że Strydon musiał leżeć niedaleko od tego miasta. Suić zatem przedstawia wyniki swoich badań według starorzymskiej zasady: Hieronymus Eusebius, Eusebii filius, domo Stridonis, natione Dalmata, civis Tarsaticensis. W ten sposób uznał jednoznacznie, że Hieronim pochodził z domu w Strydonie, który leżał w Dalmacji, a konkretnie w Liburni, w sensie administracji cesarskiej byłby obywatelem Tarsatica, opiekę duchową na mieszkańcami Strydonu zaś sprawowałby prezbiter Lupcinus, również z Tarsatica.

\section{Hipoteza Lujo Mganetića}

W 2002 roku ukazał się artykuł Lujo Magnetića, w którym analizuje obowiązki i zakres władzy w tytule comes Italiae z Notitia dignitatum oraz informacje o prowincjach zawarte w Laterculus Veronesis i Laterculus Polemii Silvini. Autor odrzuca hipotezę Suića, gdyż lokalizuje ona Strydon w Istrii, na pograniczu pomiędzy Dalmacją a Italią. Zwraca uwagę, że ponieważ w czasach Hieronima istniała prowincja Savia, informacja, którą przekazuje on sam o Strydonie leżącym na pograniczu Dalmacji i Panonii, dotyczy tylko tej części Dalmacji, która leżała obok tzw. Panonia Secunda. Panonia Secunda to na mapie (patrz mapa) sektor nr VII, więc pogranicze między nią a Dalmacją należałoby umiejscowić na terenie dzisiejszej zachodniej Bośni i Hercegowiny, na linii powyżej Bania-Luka - Doboj. Oznacza to powrót do starej hipotezy, która identyfikowała Strydon z Grahovo. Hipoteza ta budzi jedna dwie poważne wątpliwości. Po pierwsze, nadal nie mamy pewności, że Hieronim, pisząc o granicy pomiędzy Dalmacją i Panonią, miał na myśli tylko Panonia Secunda, a nie całą Panonię. Po drugie, Strydon musiał leżeć bardziej na północ, bliżej Akwilei 
i Ljubljany, gdyż inaczej niezrozumiałe są związki Hieronima z intelektualnym kręgiem akwilejskim i z mniszkami z Ljubljany (Hemony), do których pisał listy.

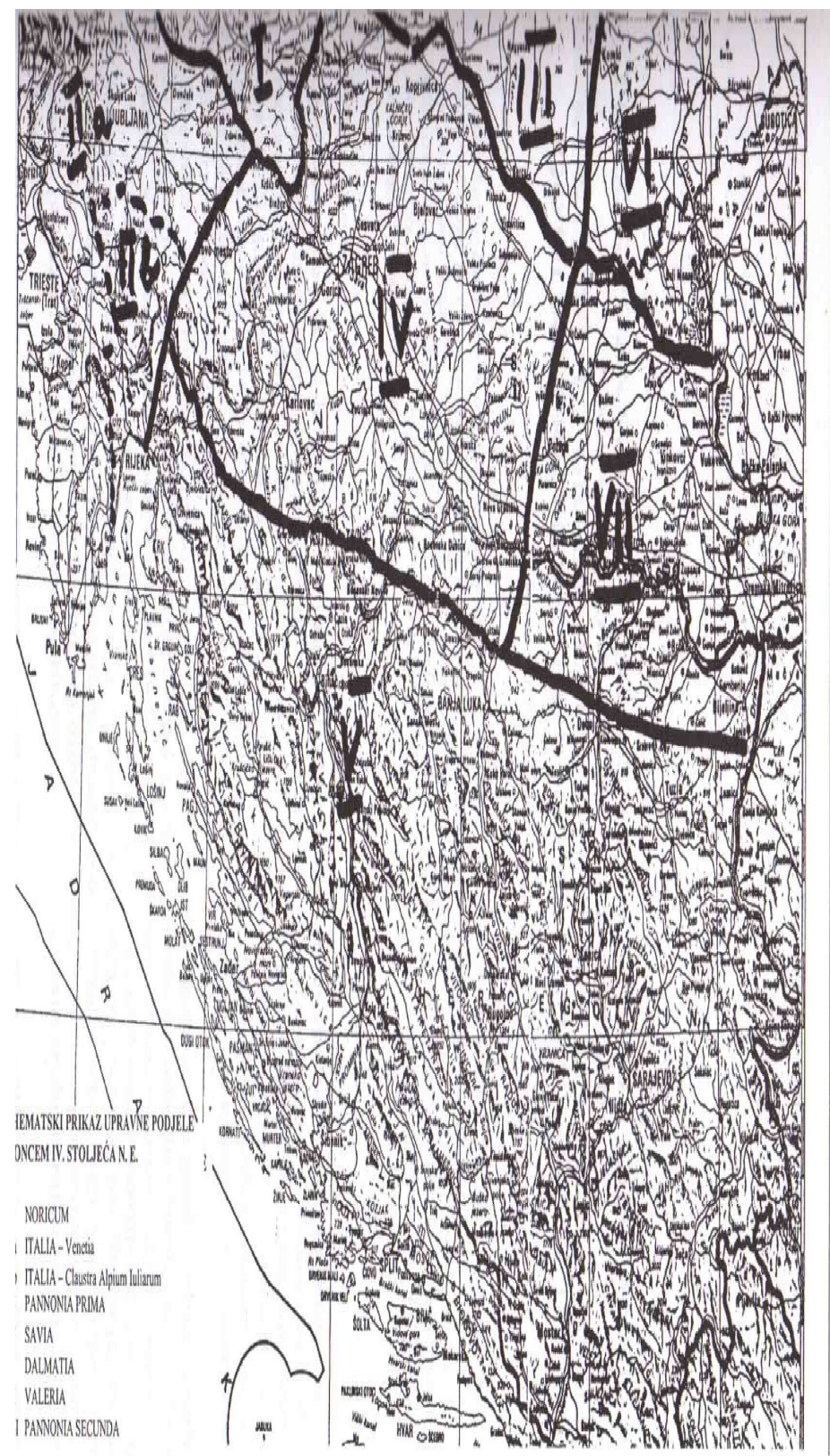


W ostatnich dziesięcioleciach archeologowie chorwaccy, słoweńscy i polscy, m.in. z Instytutu Archeologii UKSW, prowadzą na terenie Chorwacji i Słowenii intensywne wykopaliska archeologiczne. Wypada więc mieć nadzieję, że nawet jeśli nie rozwieją one wszystkich wątpliwości dotyczących lokalizacji starożytnego Strydonu, to przynajmniej przybliżą nas do prawdy. Obecnie, jak słusznie pisał Suić, większość uczonych zgadza się, że Strydonu należy szukać gdzieś pomiędzy Akwileją a Ljubljaną i najbardziej prawdopodobna wydaje się lokalizacja zaproponowana przez niego. Hieronim pochodził ze Strydonu w Dalmacji, a konkretnie w Liburni, który zarówno w sensie administracji państwowej, jak też kościelnej przynależał do Tarsatica, dzisiejsza Rijeka w północnej Chorwacji.

\section{Where was Ancient Strydon? Review of the Most Important Hypotheses of its Location}

(summary)

The first attempts to locate Jerome's Stidon Hieronim in the $17^{\text {th }}$ century were based on similarities in the sound of the names of some of today's cities with ancient Stridon and conditioned more by local patriotism than by scientific rigor. In this way Stridon was identified with Zdrinja/Sdringa in Istria, with Zrin in Medumurje in Pannonia or with Strigovo in Dalmatia. Based on the description of Jerome of De viris illustribus, Frane Bulić proposed Grahovo, but this hypothesis was rejected by most researchers. The most convincing proved to be the hypothesis of Mate Suić, according to which Stridon was in Dalmatia, specifically in Liburnia, while in the sense of state and church administration it belonged to the city of Tarsatica, today's Rijeka in Croatia. The latest hypothesis of Lujo Magnetić, who proposes to perceive the borderland mentioned by Jerome as a border between Dalmatia and Panonia Secunda, i.e. on today's Bosnia-Herzegovina, on the line above Bania-Luka - Doboj is not convincing.

Keywords: Jerome; Stridon location; Dalamtia; Panonia

\section{Gdzie leżał starożytny Strydon? Przegląd najważniejszych hipotez jego lokalizacji}

(streszczenie)

Pierwsze próby lokalizacji Strydonu Hieronima w XVII wieku oparte były na podobieństwach w brzmieniu nazw niektórych dzisiejszych miejscowości z antycznym Strydonem oraz uwarunkowane były bardziej lokalnym patriotyzmem niż rygorem naukowym. W ten sposób utożsamiano Strydon ze Zdrinja/Sdringa w Istrii, z Zrin w Medumurje w Panonii albo ze Strigovo w Dalmacji. Frane Bulić, opierając się na opisie Hieronima z De viris illustribus, zaproponował Grahovo w Bośni, ale ta hipoteza została przez większość ba- 
daczy odrzucona. Najbardziej przekonująca okazała się hipoteza Mate Suića, według której Strydon leżał w Dalmacji, a konkretnie w Liburni, w sensie administracji państwowej i kościelnej zaś przynależał do miasta Tarsatica (dzisiejsza Rijeka w północnej Chorwacji). Najnowsza hipoteza Lujo Magnetića, który proponuje postrzegać pogranicze, o którym wspomina Hieronim, jako pogranicze między Dalmacją a Panonia Secunda, czyli na terenie dzisiejszej Bośni i Hercegowiny, na linii powyżej Bania-Luka - Doboj, nie przekonuje.

Słowa kluczowe: Hieronim; lokalizacja Strydonu; Dalmacja; Panonia

\section{Bibliografia}

\section{Źródła}

Hieronymus, Commentariorum in Osee Prophetam, ed. J.J. Migne, PL 25, Parisiis 1844-1849.

Hieronymus, Epistulae I-LXX, ed. I. Hilberg, CSEL 54, pars 1, Vindobonae-Lipsiae 1910. Hieronymus, Epistulae LXXI-CXX, ed. I. Hilberg, CSEL 55, pars 2, Vindobonae-Lipsiae 1912.

Hieronymus, Epistulae CXXI-CLIV, ed. I. Hilberg, CSEL 56, pars 3, Vindobonae-Lipsiae 1918.

Hieronymus, De viris illustribus, ed. J.J. Migne, PL 23, Parisiis 1844-1849.

Mansi J.D., Sacroroum Conciliorum Nova et Amplissima Collectio, t. 2, Florentiae 1759. Palladius, Historia Lausiaca, ed. J.J. Migne, PG 34, Parisiis 1856-1866.

\section{Opracowania}

Alacevich G., La via romana da Sirmio a Salona, „Bulletino di archeologia e storia dalmata" 8 (1881-1882) s. 45-52.

Bedekovič J., Natale solum magni ecclesiae doctoris Hieronymi in ruderibus Stridonis occultatum, Neostadii Austriae 1752.

Blondus F., Italia illustrata sive descriptio XIV regionum Italiae, Bazel 1539.

Brodarić S., De conflictu Hungarorum cum Solymano Turcarum imperatore ad Mohach historia verissima, Cracovia 1527.

Bratož R., Crkvenopolitični in kulturnozgodovinski odnosi med Sirmijem in Akvilejo, „Zgodovinski časopis” 37 (1983) s. 259-272.

Bulić F., Wo lag Stridon, die Heimat des hl. Hieronymus, w: Festschrift für Otto Bendorf zu seinen 60, Geburtstag, Beč 1898, s. 276-280.

Bulić F., Dove era Stridone, la casa di San Girolamo, „Bullettino di archeologia e storia dalmata" 22 (1899) s. 137-142.

Bulić F., Stridon, Grahovo polje u Bosni, rodno mjesto sv. Jeronima, „Vjesnik za arheologiju i historiju dalmatinsku" 43 (1920) s. 60-110. 
Bulić F., Stridone luogo natale di S. Girolamo, w: Miscelanea Geronimia.a Scritti varii publicati nel XV centenario, red. V. Vannutelli, Roma 1920, s. 253-330.

Bulić F., Izbrani radowi, Split 1984.

Capor I., Della patria di san Girolamo, risposta di Giovanni Capor dalmatino, all'opuscolo del can. D. Pietro Stancovich istriano, Roma 1828.

Christ K., Historia cesarstwa rzymskiego od Augusta do Konstantyna, Poznań - Gniezno 2016.

Czuj J., Św. Hieronim. Żywot, dzieła charakterystyka, Warszawa 1954.

Danko J., Divum Hieronymum oppido Stridonis in regione interamna (Murakoz) Hungariae, Mainz 1874.

Degrassi A., Il confine nord-orientale dell'Italia romana, Bern 1954.

Fodor I., Le lieu d'origine de S. Jérôme. Reconsidération d'une vielle controverse, „Revue d'Histoire Ecclésistique” 81 (1986) s. 498-500.

Inhoffer M., Annales ecclesiastici regni Hungariae, Romae 1644, Požun 1795.

Kelly J.N.D., Jerome: His Life, Writings and Controversies, London 1975.

Magnetić L., Ieronimov oppidum Stridonis, „Croatica Christiana Periodica” 26/50 (2002) s. 1-9.

Maruli M., In eos qui Beatum Hieronymum Italum esse contendunt, w: J. Lucius, De regno Dalmatiae et Croatiae, Amsterdam 1666, s. 303-309, 457-458.

Mayer A., Die Sprache der alten Illyrien, Beč 1957.

Olahus N., Hungaria, Budapest 1536.

Quasten J., Patrologia, t. 3, Casale Monferrato 1983.

Rebenich S., Jerome: The Early Church Fathers, New York 2002.

Sanjek F., A la recherche de Stridon, lieu de naissance de saint Jérome, „Revue d'Histoire Ecclésiastique" 100/1 (2005) s. 146-151.

Samur J., St. Jerome of Stridon: His Influence on the Church, and His Translation of the Hebrew and Greek Scripture into the Latin Language (nieopublikowana drukiem praca doktorska).

Šišić F., Hrvatska povijest od najstarijih dana do potkraj 1918. sv. 1, Zagreb 1925.

Stancovich P., Della patria di S. Girolamo, dottore di s. Chiesa, e della lingua slava relativa allo stesso, Venezia 1824.

Suić M., Hieronim Stridonjanin - gradanin tarsatike, „Rad JAZU” 426 (1986) s. 213-278.

Vramec A., Kronika, Ljubljana 1578.

Ziółkowski A., Historia starożytna, Warszawa 2009. 